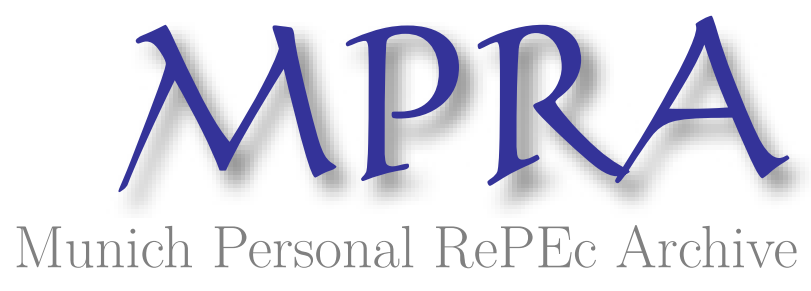

\title{
Global models and North-South relations
}

Chichilnisky, Graciela

1990

Online at https://mpra.ub.uni-muenchen.de/8126/

MPRA Paper No. 8126, posted 07 Apr 2008 04:52 UTC 


\title{
Global Models and North-South Relations
}

\author{
GRACIEIA GHICHILNISKY
}

\begin{abstract}
Anstrac1. Global modeling has ruolved remarkably in the last two decades. Such cvolution led it to perform today's role as an experimental laboralory for the social sciences, and particularly for applicacions to policy planniug. Twu of the most interesting applications to policy are to resource economics and to economic models of Nerth-South relations, i.c., the relationships between industrial and developing cauntries. Examples of North-Senth policy issues instigated by global mokteling ate developed in the cortext of a Lnited Nations - Hodel of Technology and Nenth South Relations which evolved from the Barilesthe glubal model, Furrher applications of globa] modeling are then orutined.
\end{abstract}

\section{Introduction}

Global modeling emerged twenty years ago in an eflort to arldress the world's longterm problems (Mcadows et at., 1972) and to predict important trends and crisis points. The field has evolved methodologically to become an experimental laboratory for the social sciences. This paper examines the Buriloche model, one of the first global models, and offers an analysis of its implications for trade policies and NorthSouth relations.

The carly global models were very dependent on the assumptions of their creators and on the initial data that were fed into them: this reduced their reliability and limited their usefulness for policy applications. One way to overcome these: drawbacks was to construct simplified and smaller versions of the model, and to perform qualitative analyses of the results and of the model itself.

The smaller models have the advantage that they can be subjected on qualitative theoretical analyses of policies. The global model itself remains a litboratory in which numerical experiments are performed und potential findings suggested. This process has resulted in many important policy insights, including a L nited Nations Mirlel for Technology and North-South Relations.

\section{The Last Two Decades}

Gilobal modeling has evolved remarkably during the last two decades. In the beginning it was, admittedly, naive to hope computers would address ambitious 
globat and long-term issues. At the time, it sals believed that computcrs conld provide magical solurions to new problems, particularly to large scale problems which required the athalysis of massive amounts of data and the study of complex interactions. Global modeling certainly tiruses on large issues: grcographically, it pertains to the whole world; in lime, it studies long-term problems; and intellectually, it encompasses a mulitude of disciplines.

Wurld resources, pollution, population growth, and hunger were triginally the main issues addressed by global modeling. l'en years later, as the dust created by the first threc major models (Meadows et al, 1972; Leonticffet al, 1977; Herrera ef al, 1976 ij setuled, it became clear that computers are not omnipotent. Disenctuntment with their ability to solve humanity's largest and most difficult problems sec in, and led to the atcmpt to incorporate more traditional scientific tools into global modeling. Feonomics was iutroduced to study the world's resources and the world's basic needs (Chichilnisky, 1977); socioingy and political science to study world scenarios (Cole and Niles, 1981; Cole et al 1973; Frecman and Jahoda, 1978) socinhogy and political science to stady asperts of resources and pollution (Heal, 1973 ?.

Global modeling becarne more respectable as it integrated with the cstablished thisciplines. Yet its bold insistence that the world as a whole mattered and that it could be studied as a scientitic object. albeit by less corventional moans, remained unchinged. Clobal modefing atso conimued to provide a link between computer technolosy and the social scicnces, rhus ereating an experimentat laboracory through which social scientisis could exploce issues and problems, rather than turning lo computer systems to resolye them.

\section{Structural Stability in Global Models and in the Social Sciences}

One of the problems global modeling has faced from the outset is the extreme sensitivity of the results to the mathernatical assumptions of the models and the models' initial data. Siructural stability refers to the "robustness" of the results to strall errors or omissions in the intial data (including both parameter values and functionat specifications). Without it, very small variations in the data cari lead to drascically different restils, and therefore the results are nu "robust" or reliable.

Consider, for example, the hypothesis that resources are fixed, while population is growing exjonentially. For that matter, consider a linear increase in resources, with an expencntial growth in population. Simple arithmetic shows that a catastrophe svill occur; the population will run out of resources. This will also occur, unless resources grow at least in a similar exponential fashion, It is clear that the assumptions made. on the rates of growth of the different variables determine to a grcat cxtent the results. This means that the results are extremely sensitive to the assumptions, and in particular to the mathematical assumptions, which are usually less obvious to the reader than other types of assumptions. In the above cxample we do not need a computes th predict a catastrophe. Wo do not necd to analyze large amounts of data either. Futhermore, and this is the point about structural stability; the specific date of the catastrophe depends strongly on the mathematical assumprions about the differene rates of growth of the differcnt variables, which are the initial data of the model. We are, in effect, dealing with issues of sensitivity analysis: this is the study of how the results depend on the assumptions and the initial datat.

A model is "strusturally stable" when its qualitutive resuits are independent of 
small changes in the assumptions and the inirial datia. Given the pauticy of data in the areas studied by global models, as well as the mocrtainty underlying the measurement of data, strurcural stability is clearly an important feature: it guarantees that small mistakes or omissions in the assumptions and intial data do mit radically alter the results. We can, therefore, rely on the results despite the fact that the data are imperfect, and that our assumptions may be a bit off

The desirability of structural stability extends to most areas in the social sciences. The reasons are the same: the results are very dependent in the assumpoions, and lack of proper data, or small errors in the observations, are more the rule than the excrption in the sorial sciences. This is an important methodological difference between the social and physical sciences.

This issue of structural stability lies behind many of the criticisms made of the. results of the "I Limits to Growth" exercise. It was the thrust behind the development of the. Bariloche model, which ser out in 1970 to answer the worst predictions of the "Limits to Gimsth" for the developing countries, so as not to exhaust the worids resources, or diternatively their position in the world ecunomy withour threatenug, other countrics.

These results were secn as a threat to the eflints of developing councrics to imptove their position in the world, in an cra when the "Vew International Lconomic Oreter" was introduced proposing advances for the developirg cormiries hy moans of cconomic growth. The Bariloche model saw the "Limits to Gmowth" results as a simple consequence of certain assumptions, which were considered as macceptabic. belween population growth in the developing countries, per capita consumption ot resourtes in the developing countries atid in the world. and certain exponental itssumptions about population growth. Mure importantly, Bariloche saw the "Limbs is Growth" exercise as assuming that human beings do not adjust in their enviromment, since the trends of the different variables (e.g.. consumption patterns, and resource availability and their rolutionships, ate assumed to proceed blindly without any corrections even as the catastrophe nears. Mathematically, there art no functional adjustments becween the different trends.

We used the Bariloche model to investigate alternative assumptions and the resules which would ensue, again using a computer model of the worid cconomy, but this rime assuming cortain rational leatures or adjustments of the economic airtuts, the maximization of consumption of "basic necds," a term which was introduccet by Bariloche for the first time in the literature and which had a widespread and illustrous following throughout the world for matry years. As the author of the romomic model within Bariloche, $\mathbf{I}$ still remember the inceduticy encountered in aving in introduce such a novel concept within an cconomic medel of a traditional cype-

Of course, as Bariloche made different assumptions, it obtained differene icsules: in particular, it found that the growth of the developing councries was indeed possible within existing resources and reasonable assumptions, provided ecronomic agents were rational. It also found that developing countries did not threaten the world eronomy in their attempes to grow: no surprise here. However, at the policy iecel, both "Limits to Growth" and Bariloche encountered the same difticulty: How much structural stabiliry did those models have? in order to use the resulis fin policy analysis we needed to know how much the results depended on the numerical and functional assumptions and how much was, instead, an intrinsic property of the structure built into the model by its athors. Rephrasing this: Wis Bariloche structurally stable? Was "I imits to Growth" structurally stable? 


\section{From Bariloche to the United Nations Model: Technology and North-South Relations}

A large global model is a time-consuming exercise, as any of the authors will attest, and Bariloche was no cxception to this rulc. Thers was little time to study methodological issues which were outside its scope, such as the question of structural stability. Yel this question remained and its importance became to me clearer as time passed. This is partly because, disguised as a methodological question, this was at major issue in deciding the desirability of alternative economic development policies.

In 1978 the UNITAR Project on the Future, Jed by Philippe de Seynes, gave me the opportunity to co-direct a United Nations project which we called "Technology and North-South Relations." This project was to produce a global model that would revise Bariloche and focus on North-South issues of importance for the United Nations development strategies. Technology was certainly one such issuc; NorthSouth relations was another. Here I was given a unique opportunity to improve upon the shortcomings of the Bariloche model which still haunted me. I could add a market structure, and prices as a most important class of variables in the economic model (Bariloche did not contemplate markets or prices). Thus I could really look at the issue of structural stability and dig deeply into the structure of the world model which we produced, in cooperation with my team at Harvard and Columbia Universities, and with anther team led by $\mathrm{S}$. Cole at Sussex University (Chichilnisky, 1980: 1981: 1983: 1984a: 1986\%.

As already mentioned, the methodological issue was really a cover for some of the most interesting policy issucs 1 have cncountered in many years. Judging by the intcrest and the published comment and cricism generated by the work follonving publication of the United Nations model in the Journal of Development Economict in 1983 and 1984, and in other journals and books, it was apparcnt that others were also attracted to these issues. The policy issues involved include sonte of the major concerns in international trade policy: the desirability of export-led growth and of specialization into "relative advantages"; the international marke's rule as an "engine for growth", and the role of aid in sustaining development.

From now onwards I will refrain from discussing the methodological issue of structural stability except in the context of these major policy issues: it will be more fitting to the theme of this journal issue to do so. But I musl alert the reader that the methodological issue is not exhausted by these policy examples, It is a fundamental issue within the social sciences and it deserves to be treated as such, in its proper contex1.

\section{Global Models and North-South Relations}

The first task of our United Nations project "Technology and North-South Relations" was to producc a model which would deal best with the major policy issue of developing countrics. The starting point was the question of satisfaction of basic: nceds, an issuc central to the Bariloche model. Producing the L nited Nations model was a demanding task because most existing economic models were manufactured with the industrial countries in mind, and therefore were not adequate for the study of devcloping countries. For example, a country's demand was typically aggregated into one economic statistic, thus preventing the study of certain fundamental issues regarding the difference in demand by different groups-i.e., the distribution of inconne. 
He decided that one of the most interesting and difficult issues which had to be addressed was how different policies affected different income groups, and for this we disaggregated demand by income groups. This leads to the problem of how to divide the population into different income groups in a meaningfil way that is, in a way which woukd actually be useful in understanding the impace of alternative policies.

To arhieve this, the separation of goods into different types was required, particularly types of goods which were consumed in different proportions by the different income groups. Similarly, market prices became quite important, because otten (voluntary) policies are followed by (involunlary) price changes. For example, tariffs lead to changes in marker's relative prices. Price changes have a welfare effect of their own, affecting the income groups which consume most intensively the goods whose prices have changed. Such welfare effects could, therefore, work in the opposite direction from that which was initially intended.

With these problems in mind we created a global model with several income groups, and where goods were disaygregated according to their consumption by the different groups. Prices for the different goods were determined by marker forces. For example, basic goods were introduced. defined ats a bundle of gorols which were consumed most intensively by the lowest income group. Each region was mudeled as a marke. economy which produced and consumed several groups of goods, and which had several groups of consumers cach consuming at group of goods in different propartions.

Having modeled each region accordingly, we set out to model the international economy, and then proceeded to compute international market equilibria. All goods were internationally traded, and the international market, save for tariffs where applicable, was assumed to be competitive. An algorithm was developed to compute the solution, which for simplicity described a positive arljustment between goods exported and their prices until at market clearing equilibrium was reached, under the assumprion that if more goods were exported, international demand should have. increased, and this would naturally lead to higher prices. The purpose was to approximate an "export-led" policy, in which the developing countries faced a larger demand for their products, and cxported more.

At this point our experimental laboratory, the numerical global model, started producing surprises, More exports were associated with lower, not with higher, prices, even if the increase in exports derived from an increase in the demand from the rest of the world. After considering several possibilities, including, of course, numerical errors, we had to admit that in the world represented by this model a policy resulting in the North (the industrial countries) importing more from the South (the developing countries) lowered the prices for the South's exports. Since these exports are labor intensive, this in turn led to lower wages, to lower levels of output, and to lower levels of employment in the South as well. In the logic of the model, increasing exports reduced the welfare in the South.

The surprises did not end here. The numerical results also showed that the North was consuming more of all goods in all income levels due to the added purchasing power derived from lower import prices. The policy which led to increasing imports in the North was beneficial for the North but certainly not for the South. It is important to note that all of this took place in stable markets; if the world's demand for a product increased, then prices increased correspondingly. The reason was that as the North's demand increased, the South's did not, thus prices did not increase 
with an cnlarged matket for exporls. Fiven with stability, exporting more was to lietlet for the South: it was worse, So much tor exprnt-led policies.

Having reached such a poinc, the only alternative open th the scientist is io thy 10 understand the reasons profiucing these results from the numerical expeniments. The pesules did not appear to tally with existing theory, although in fact, they did. These

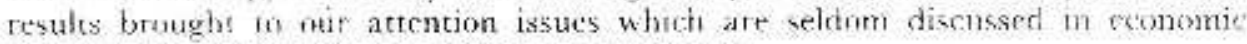
theory, and which wert nor understood uncil them.

These issues an be described as follows: if a country is exporting a labur-intenswe commodity moxtly consumed by wage earners. and if the country s demand response to protes is sfrong white supply responses are ucak, then any increase in profes of basic goods increases domestir demand more than domestic supply, thus lowertig cxports. Luder these conditions, the unily way exports can increase is by lowerings rhtmestic demand, whth in turn is achieved by lowering wage income, and reducing emplovment and producdion. The increase in cxports sould be accompaned by all imcrease in imports by the rest of the wortd but this does not alter the results. A dismat outcome, but a vers real one: subsequent empirical studies arreced wate the

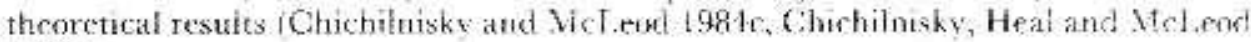
$1984 \mathrm{~d}$ :

This outcome was understood onty ater simplitving the global modet to a twetcountry two-good molet, smilar o the classical liecksher-Ohin modet, but hitvitg two differing leatures: (1) the supply of lactors icapital and labor) is not fixed and i1 inreases strongls ith the South depending on prices, and, (2) Irehnelogies are ditierent in the two regions. Fo the south the modern and che traditionat sectors differ considerabiy, while the North exhibits a milies distributimat homogencous trehnotagy across its cntire economy. These lwo features were denoted abundant labour supply and dual terinoligeies, resperisely. 'The Jorth was construed to be homogencous, and its factors to be relatively supply imelasi

In the context of a simphified model, these results were prover by mathematical theorems; in which the above cunditions weste formalized. The consequences of export-led policies already discussed were fotmaliy prexent for matkets with alt stability properties.

These results for exjori-ied polscies in the Snuth with abmolant habot and dua!

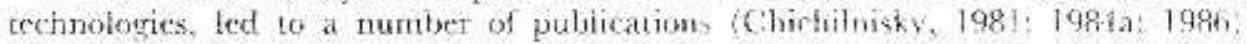
These bed in curn to very consicterable comment asel srickessm in the forernol gy

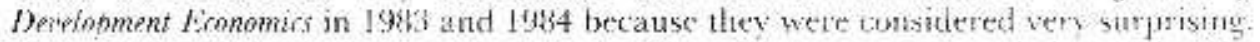
As ro be expected, they were not wetcomed by advocales of expost led grow th. The issue was complicated further because a cortan mathernatical dexlerily was neressitry of prove the above results, which secne beyond the average level in conventionat trade theory eflestively introducing new theoreticat tools in the field.

As the theory became betce understood, it becme possibie to detcrmine the range of parameters under which such results could ocent, and those under which the opposite woutd liappen. Fxport-led prolicies then could only be advised in the latter case bet not in the former. The range of paramelers determining the outcome included technotogy parameter: such as the imput-output coefficirsuts in the production funcrions of the different goods. Thus, technological considerations wuld bo used to recommend export-led policses, or to the comtrary, th asoid them. Reciprocally, if export-led growth was a goal, certain technologics were needed to guarantec positive resulis. Technology and basic needs were thus tied up in export- 
ted policies. by meatus of the experimentes with a globid model.

A sccond experiment was conducced relaed to another major issue in North Sinurh reliations: fureign al. A similar sequence of events, wiach be now the reacier can reconstruct withouc natrative. led to a theorem proving that in stabie worid fenomies with at least chree conntrics, a donor councry can matke itscif better off. and make the resewing country worse dif after the aranster aid from the former to the laltes. This uccurs as a result uf ile impact lor lransler has on equilibrium prices, which revets the primaty positive effect of the transfer into a tiegative orte called the iransfer paradox. The same results tieke place after onc eounery distooses of some of the

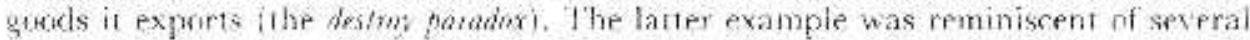
incidents involving the destruction of eoffee and ather basic export crops in developing countries.

The first issue, nante the tamster paradox, was a classical problem in trade theory going back to fohn Stuart Mill but with an important tusst. In the 1950 s Paul Samuetem bad contended that this paradox conid only happen in ansiable markets. arel thetefore that it was of litte practical interest. The stable results of Chichimiskv (Chichilnisky, 1980: 1983, 1984b) took several athors by surprise lending to a large number of phblicacioms intended to dacity and expiane the results

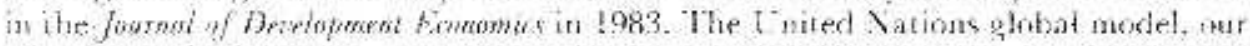

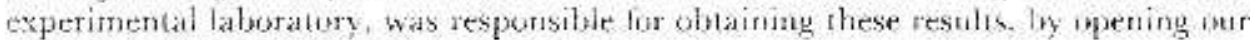
cyes to possibilities uat ervisayed befine.

The acxe step following the theoreticat andysis is the actual fitting of the rnotel to data, and the deveiopment policy recommendations. This was achicked in a uumber of publications, (Chichilnisks, 1981: 1984a; 1986. Chichilnisky and Cole. 1978) dealing with specific countries as well as with the gobal eronomy (Chichitnisky, $1944 c$, dil.

The therretical anatvis of reduced sersons of the ginbal models, which ted to the understanding of these results, disciosed also the degree of stability of these conclusions. In each case. a range of paramesers was identified wirhin which exportJed poticies nould be laverable, on mol, and in the batter cast, where did would have 4 favorable eflect in not. The structural srabiliry of the results was escablished. This meant that within a wide mage of parameters we were asstered that the qualitarive predictions would be preserved. Despite small crrors of vbservations, we could still appiy the results of policy analysis with a certan measure of confidence:

\section{Export-led Policies and Aid: Two Major Issues of North-South Relations}

These two major policy issues. che impact of aid and of cxport-led policies, served If illustrate the applications that glohal modeling has had to North-South relations. The numcrical global model used as an experimental laboratory disclosed rather mexpected results which had not been known before. The analysis of smaller versions of the model led to new theories and to new insights into proticy, all based on the experimental labuatury prowided by the glabal modiel.

This is in at wav the most successful type of application of ylobal modeling in the social sciences. It points to a smaregy which rejresents a substimte for experimemal work which can be: pertormed and which, along with theorv. ieasls on a desimabie balance of borth. 


\section{Conclusion}

The last twenty years have witnessed major changes in global modeling. It was initially a tather dittuse and all-cncompassing computer discipline addressing major global issues and detecting points of crisis and possible solutions. It is now mostly a substitute for experimental laboratorics in the global agenda.

We have discussed the evolution of global modeling; using as an example that of the Bariloche model, one of the first global mudels, into the Linited Nations model "Technology and North-South Relations." The former was used to investigate humanity's ability to satisfy hasic needs; the litter, to focus on and evaluate more specific trade policies and other major issues of . Forth-South relations, such as aid. In the process of developing the model a mothodological question, the structural stability of the results, led to a ncw modeling methodology. Global models were used for conducting policy experiments and to test numerical responses; smaller versions of the model were used to investigate in depth the structure of the results, and their reliability for policy. The global model itself remains an experimental laboratory for the social sciences.

\section{Notes}

1. The Bariloche model is an interdisciplinary iampuntrized undel of the world economy divided into five regions, which correspond roughly 11 the continents. It was created by a Leam of Third World scientists in Fundacion Bariloche. Previncia de. Riu Negro, Argrntiniz, betwren 197 and 1976, and subsequendy published in several languages. The thrust of the model was its cconomic: model, a matlematical one that introduced and defined the concept of Basic Needs, and put this concept at the center of the development ofjurtives, or plans, for Third World countries and the world economy. I was the author of the concept of Basic Needs, and of the economic model of Bariloche.

2. The Heckscher-Ohlin mendel depicts a world economy with cwo countrics for regions; which trade with cach other in a competitive market fashion. Factors of production are lator and capital. Both regions use the same tectunologies or production functions to produce two goesh.s. The Iwo regions are identical except for factor endowments. One is labor-rich; the other is capital-rich. The reason they trade is their mative ardvanlages: Ito labur-rich region exports the labor-intensive goods and the capital-rich region cxports the capical-intensive goods. This model is taught as a foundation of international trade, but it has been shown in the empirically incorrect for alsout 50 years.

\section{References}

Chichilnisky, G, 1477). "Fconomic Development and Efficicncy Critcria in the Satisfarlien of Basic Needs." Applied Mathematical Modeling. 1(6): 290-298.

Ghichilnisky, G. (1980), "Basic Goods, the Liflects of Commodity Iransters and the International E.conomir Order.: Journal of Development Economics. 7: 505-519.

Ghichilnisky, G. (1981). "Terms of Irade and Demestia: Distritulion: Fxport Led Growth with Abundant Iatwor," Journai of Detelopment Economics. 8: 153-192

Chichilnisky, G. (1983). "The Transfer Problem with Three Ageuts Oncr Again: Characterization, Uniçueness and Stability." Joumal of Dezelopment Economics. 13: 237-248.

Cliichilnisky, G. [1984al. "North-South Trade and Export Led Policies." Joumal of Deirlopmens Economics. 15: 131-160

Chichilnisky, G. (1984b). "The Transfer Problem in Stable Markets: A Rejoinder to Rejoirulers." Journal of Dretiopment Eionomics. 16: 319-320.

Chichilnisky, G. (1984c). "Agricultural Productivity and Trade: Argencinat and the USA". 
(with D. McLeod), Working Paper No 1984-5, Octotser 1984, Global Analysis and Prijections. The World Bank.

Chichilnisky, G. (1984d), "Resources, Trade and Debt: thr Gast of Mexicar" (wilh G. Heal and D. McI.eodi, Division Paper 1984-5., Nowember 1984, Global Analysis and Projcctions: The World Bank.

Chichilnisky, G. (1986)- "A General Equilibrium Theory of North-South 'Trade." Eissavs in Honor of K.J. Arroce, vol. 2, Ch. 10 iW. Heller, D, Starret and R. Starr, reds). Catmhidge AA: Cambridge Iniversity Press.

Chichilnisky, G, and S. Colc, (1978). "A Model of Technology, Distribution and North South Relarions." Technological Furecasting and Sewinh Change. 13/4i!: 297390.

Cole, S. and I. Miles. (1984). Horlds Apart. New Jersey: Rowman and Allenheld.

Cole, S., C. Frecman, M. Jahoda and K. Pavitt (1973). Thinking abou the Fulue Iondun: Chato and Windus.

Freeman, G. and M. Jahoda (1978). World Fitures: The Creat Debate. Londoni Martin Robertson.

Heal, G. (1973), "The Depletion of Exhaustible Resources," In Consmporary Isnues in Econamics, (M. Parkin and A. Nobay, eds). Manchester: Manchester Lniversity Press.

Herrera, A., G. Chichilnisky et af. (1976). Catastrophe or Veat Society Ottawa: IDRC.

Leontief, W.A. A. Garter, and P. Petri (1977). The Fuiure of the World Fconoms - A tinited Nations Study. New York: Oxford University Press.

Hcadows, 1).11. D.L. Meadows, J. Ranters, and W.WF. Bchrens 111 (1972). The Limits to Groutich. New York: Universc Books.

\section{Biugraphical Note}

Gractita Cinichilsisky is Professor of Fonomics at Columbia University, New York. She taught previously at Harvard University and the University of Fssex, and part of the Bariloche model, and coauthor of the United Nations Model of Technology and North-Sourh Relations. She has published numerous scientific articles and several books in the areas of mathematics and comomics, and her most recent books are The Evolving Intermational Economy, Cimbridge: University Press (1987), coauthored with G. Heal, and Oil in the Intemational Economy, Oxford University Press (forthcoming).

ADDREss: 33 B Riverside Drive, Jew York NY 10025, LSA. 